\title{
Enzymatic synthesis and characterization of polycaprolactone by using immobilized lipase onto a surface-modified renewable carrier
}

\author{
Cansu Ulker*, Nurefsan Gokalp, Yuksel Guvenilir \\ Istanbul Technical University, Department of Chemical Engineering, 34469, Istanbul, Turkey \\ "Corresponding author: e-mail: ulkerc@itu.edu.tr
}

\begin{abstract}
In the present study, rice husk ash, which is a renewable and abundant material, was utilized as a carrier for lipase immobilization for the first time. Poly ( $\varepsilon$-caprolactone) synthesis was successfully achieved by the new enzymatic catalyst: Candida antarctica lipase B immobilized onto surface-modified rice husk ashes by covalent binding. It was aimed to obtain optimum polymerization conditions at which highest molecular weight was reached and characterize the polymer produced. Moreover, thermal stability and effectiveness of the new biocatalyst in non-aqueous media were also shown with successful polymerization reactions. In addition, by using the new enzyme preparation, $\varepsilon$-caprolactone was able to be polymerized even at $30^{\circ} \mathrm{C}$, which was promising for an energy saving process. Consequently, this work provides a new alternative route for poly ( $\varepsilon$-caprolactone) synthesis.
\end{abstract}

Keywords: enzymatic polymerization, ring opening polymerization, enzyme immobilization, lipase, renewable carrier.

\section{INTRODUCTION}

Among aliphatic polyesters, poly ( $\varepsilon$-caprolactone) (PCL) became an attractive material for biomedical applications as a result of its biocompatible, biodegradable, and permeable nature ${ }^{1,2}$. In general metallic catalysts are used to polymerize $\varepsilon$-caprolactone $(\varepsilon-\mathrm{CL})$ via ring opening. However, metallic residues that could not be fully removed after reaction, may cause harmful effects for medical implementations ${ }^{2,3}$. Enzymatic polymerization overcomes this problem by avoiding toxic residues in the product. Moreover, enzymes provide mild reaction conditions, high enantio- and regio- selectivity and they can be easily recycled ${ }^{2,4}$.

$\varepsilon$-CL has been polymerized via various type of lipases such as Porcine pancreatic lipase, Candida rugose lipase, Pseudomonas flourescens lipase, and Candida antarctica lipase B (CALB) by this time ${ }^{3}$. Among these lipases $\mathrm{Can}$ dida antarctica lipase $\mathrm{B}$ and its acrylic resin immobilized form (Novozyme $435^{\circledR}$ ) are known with their efficiencies and high catalytic activities during PCL synthesis ${ }^{5}$.

During polymer synthesis, which is carried out under harsh conditions (such as high reaction temperature, long reaction time, and solvents used during reaction) for a biocatalyst, it is troublesome to keep enzyme active and stable ${ }^{2}$. However, by immobilization, enzyme activity and stability can be improved, enzyme can be recovered at the end of the reaction and reused ${ }^{6,7}$.

There are a variety of methods used to immobilize enzymes. Three of the most common are adsorption, entrapment, and covalently binding to a support material with a cross-linking agent. Adsorption involves the enzyme being physically adsorbed onto the support material, often a polymer matrix or an inorganic support. Entrapment involves entrapping enzyme in either the lattice structure of a material or in polymer membranes. This usually minimizes enzyme leaching and improves stabilization, but frequently results in transport limitations of substrate to the enzyme active site. Enzymes may also be immobilized through cross-linking of the protein to an insoluble support to prevent the loss into the substrate solution, or covalent binding to a functionalized support ${ }^{8-10}$.
Rice husk ash has a silica content of $95 \%$ of its dry weight and shows amorphous silica properties which make it a suitable porous support material for lipase immobilization ${ }^{11}$. Moreover, by the silanization of $\mathrm{Si}-\mathrm{OH}$ groups on the surface of rice husk ash, the ash turned to more active for immobilization process ${ }^{12}$.

In this study, a new alternative immobilized CALB (im-CALB) was employed for PCL synthesis. Immobilized biocatalyst was previously obtained by the covalent binding of CALB onto a renewable carrier, rice husk ash, which was modified by silanization of its surface to enhance immobilization process. PCL synthesis was carried out in toluene medium under nitrogen atmosphere for various reaction temperatures and periods. Also, different enzyme concentrations were tried. Moreover, polymerization performance of new biocatalyst was compared with free CALB and Novozyme $435^{\circledR}$. Molecular weights were obtained from Gel permeation chromatography (GPC) and chemical structures were characterized by Fourier transform infrared spectroscopy (FTIR) and Hydrogen nuclear magnetic resonance spectroscopy ( ${ }^{1} \mathrm{H}$ NMR). For the thermal analysis of PCL samples, Thermal gravimetric analysis (TGA) and Differential scanning calorimetry (DSC) were applied. Surface morphologies were characterized by Scanning electron microscopy (SEM).

\section{MATERIAL AND METHODS}

\author{
Material \\ The free form of CALB (Lipozyme ${ }^{\circledR}$ ) and Novozyme \\ $435^{\circledR}$ were kindly provided by Novozymes (Denmark) \\ and used as received. Rice husks were supplied by \\ a rice production company (Edirne, Turkey). They were \\ washed with distilled water and burned at $600-650^{\circ} \mathrm{C}$ \\ for 6 hours to obtain rice husk ash (RHA). Surface \\ modification of RHA was achieved by the silanization \\ agent 3-aminopropyl triethoxysilane (3-APTES) (99\%, \\ Merck). Glutaraldehyde (25\%, Merck) was used to \\ covalently bind enzymes to the surface-modified RHA. \\ $\varepsilon$-caprolactone was obtained from Alfa Aesar and stored \\ over molecular sieves before polymerization to avoid
}


water. Toluene was purchased from Merck and used as a solvent in polymerization reactions. Chloroform was used for termination of the polymerization reaction and provided from Sigma Aldrich. For precipitation of the polymer, methanol was used and it was obtained from Merck. All other chemicals were analytical grade and provided either from Merck and Riedel de Häen.

\section{Surface Modification of Rice Husk Ash}

Surface of the renewable silica-based enzyme carrier, rice husk ash, was modified by silanization reaction with 3-APTES. $250 \mathrm{mg}$ of rice husk ash was mixed with determined amount of 3-APTES in $5 \mathrm{~mL}$ acetone. The mixture was incubated in shaking water bath at $50^{\circ} \mathrm{C}$ and $160 \mathrm{rpm}$ for 2 hours. At the end of the reaction, surfacemodified ash was washed with distilled water to remove unreacted compounds and dried at $60^{\circ} \mathrm{C}$ for 2 hours.

\section{CALB Immobilization onto Rice Husk Ash}

CALB was immobilized onto surface-modified rice husk ash via covalent binding with glutaraldehyde. Surface-modified rice husk ash was mixed with calculated amount of glutaraldehyde in $25 \mathrm{~mL}$ sodium phosphate buffer solution $(\mathrm{pH} 7,0.015 \mathrm{M})$ at room temperature for 2 hours. At the end of the reaction, the product was washed with distilled water and filtered under vacuum. After that, it was dispersed in $25 \mathrm{~mL}$ of same sodium phosphate buffer containing determined amount of free CALB $(570 \mathrm{mg} / \mathrm{mL})$ at room temperature for 5 hours. The immobilized enzymes were filtered and washed with the same sodium phosphate buffer and dried overnight at $30^{\circ} \mathrm{C}$.

Activity and protein content of im-CALB were determined by titrimetric and spectrophotometric methods, respectively ${ }^{13}$. Immobilization efficiency was calculated from the ratio of protein coupled to the carrier and protein loaded ${ }^{\mathbf{1 3}}$.

\section{PCL Synthesis via Immobilized CALB}

Ring opening polymerization (ROP) of $\varepsilon$-CL was carried out by immobilized CALB (im-CALB). Reactions were performed in $1 \mathrm{~g}$ of toluene under dry nitrogen. $\varepsilon-\mathrm{CL}$ to toluene ratio was 1:2 (w:w) and enzyme concentration (ratio of enzyme to monomer) was $20 \%$ in weight. Reaction medium was stirred at $120 \mathrm{rpm}$ with a magnetic stirrer. Reactions were carried out at 30, 40, 60 , and $80^{\circ} \mathrm{C}$ for $6,24,48,72$, and 120 hours. Reactions were terminated by the addition of excess chloroform to the mixture. Enzyme was separated from the reaction mixture by filtration. Then, chloroform was evaporated. After that, by the use of cold methanol, polymer was precipitated. The polymer sample was washed with methanol and filtrated. Then, the sample was dried overnight at $30^{\circ} \mathrm{C}$.

Each reported value was the mean of three experiments at least, and the standard deviation was within ca. $\pm 5 \%$. Also all results are reproducible.

\section{Characterizations}

Polymer samples were analyzed by FTIR in order to define the chemical structure and verify them to be PCL by comparing with characteristic IR bands of PCL. In addition, surface modification of rice husk ashes was also confirmed by FTIR. Each sample was analyzed by $\mathrm{KBr}$ pellet. The spectra were recorded by at least 32 scans with a resolution of $2 \mathrm{~cm}^{-1}$ in a FTIR spectrophotometer (Perkin Elmer).

Thermal characterization of polymer samples and rice husk ashes were carried out by TGA on 5-10 mg samples by heating from room temperature to $1000^{\circ} \mathrm{C}$ at $10^{\circ} \mathrm{C} / \mathrm{min}$ under nitrogen using a Seiko TG/DTA 6300 .

Further thermal properties were determined by DSC (SEIKO 7020). Under inert nitrogen atmosphere 10-15 mg samples were analyzed. The materials were exposed to thermal cycles (heat-cool-heat). Thermal characterization was carried out between -70 and $200^{\circ} \mathrm{C}$ at $10^{\circ} \mathrm{C} /$ min. By DSC analysis, melting temperature $\left(\mathrm{T}_{\mathrm{m}}\right)$, melting enthalpy $\left(\Delta \mathrm{H}_{\mathrm{m}}\right)$, and crystallinity percentage $\left(\mathrm{X}_{\mathrm{c}}\right)$ were obtained. For the calculation of crystallinity percentage $\left(\mathrm{X}_{\mathrm{c}}\right)$, Equation 1 was used ${ }^{14}$.

$X_{c}=\left(\frac{\Delta H_{m}}{\Delta H_{m}^{\circ}}\right) x 100$

In Equation1, $\Delta \mathrm{H}_{\mathrm{m}}^{\circ}$ is the melting enthalpy of PCL where it has $100 \%$ crystalline structure and its value is $139.3 \mathrm{~J} / \mathrm{g}^{14}$.

GPC was used for the determination of molecular weights and polydispersity indexes (PDI) of PCL samples. Measurements were carried out by Agilent 1100 model GPC apparatus which was calibrated based on polystyrene standard. Tetrahydrofuran (THF) was used as an eluent with a flow rate of $1 \mathrm{~mL} / \mathrm{min}$. Before injection, all samples were filtered via $0.45 \mu \mathrm{m}$ filter syringe.

${ }^{1} \mathrm{H}$ NMR was applied for the determination of molecular weight and molecular structure of polymer samples (Bruker Ultrashield $300 \mathrm{MHz}$ ). Deuterated chloroform $\left(\mathrm{CDCl}_{3}\right)$ was used as a solvent during analysis. ${ }^{1} \mathrm{H} \mathrm{NMR}$ spectra was obtained with respect to tetramethylsilane (TMS) standard. Molecular weight $\left(\mathrm{M}_{\mathrm{n}}\right)$ value of PCL was calculated based on the areas of peaks obtained at characteristic chemical shift $(\delta)$ values of $4.07 \mathrm{ppm}$ $\left(\mathrm{CH}_{2} \mathrm{O}\right)$ and $3.65 \mathrm{ppm}\left(\mathrm{CH}_{2} \mathrm{OH}\right.$, end group). The formula used for $M_{n, N M R}$ calculation was given in Equation $2^{\mathbf{1 5}, 16}$.

$M_{n, N M R}=\frac{5 x I_{4.07}}{2 x I_{3.65}} x M_{\varepsilon-C L}$

In equation $2, \mathrm{M}_{\varepsilon-\mathrm{CL}}$ is the molecular weight of $\varepsilon-\mathrm{CL}$, $\mathrm{I}_{4.07}$ and $\mathrm{I}_{3.65}$ are the integrated peak areas ${ }^{\mathbf{1 6}}$.

Surface morphology of polymer samples were observed by SEM (JEOL JSM-6390LV). Samples were coated with platinum before observation. Analysis was performed at $5 \mathrm{kV}$ with different magnifications.

\section{RESULTS AND DISCUSSION}

\section{Surface modification and immobilization results}

Surface modification of RHA by 3-APTES was characterized by TGA analysis. Weight losses of neat RHA $(1.03 \%)$ and surface-modified RHA (2.20\%) were compared at $190^{\circ} \mathrm{C}$, at which 3 -APTES evaporates ${ }^{17,18}$. The difference between the weight loss percentages shows that surface modification was achieved successfully (Fig. 1). Moreover, FTIR analysis was also carried out for neat and surface-modified rice husk ashes. Appearance of peaks around $3050 \mathrm{~cm}^{-1}$ showed the addition of $-\mathrm{NH}_{2}$ groups to the surface by treatment with 3-APTES (Fig. 2) ${ }^{\mathbf{1 7}}$. 


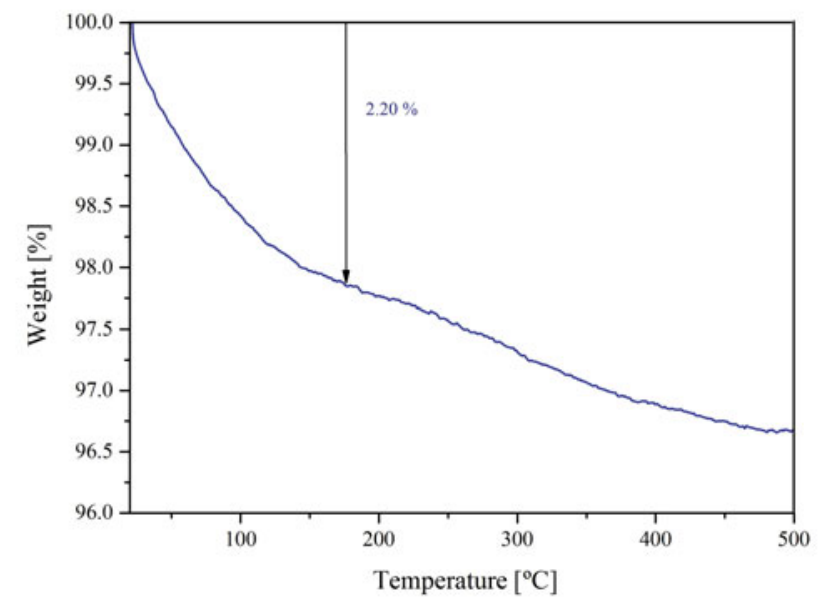

Figure 1. TGA curve of surface-modified RHA

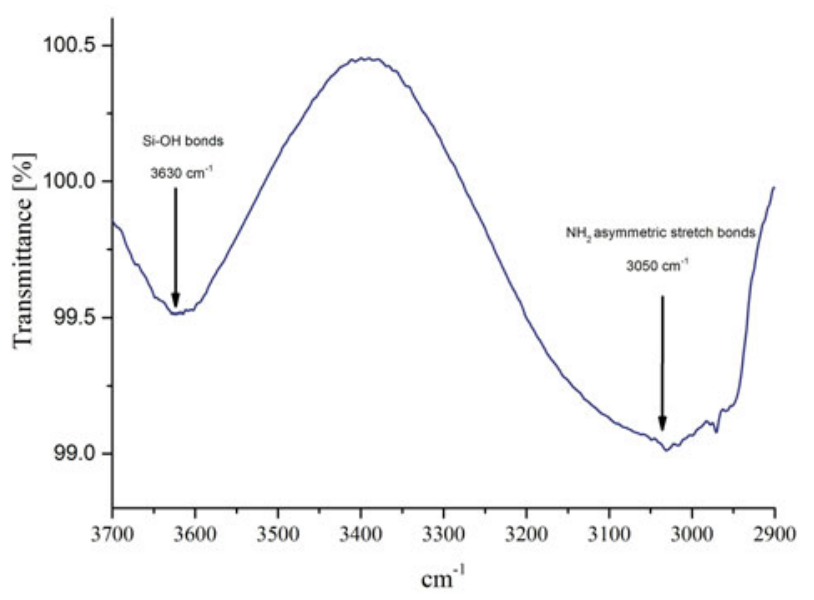

Figure 2. Partial FTIR spectrum of surface-modified RHA

After immobilization of free CALB onto surface-modified RHA, im-CALB was obtained with an immobilization efficiency of $90 \%$. The activity of im-CALB was measured as $2050 \mathrm{U}$, with an only $20 \%$ loss after immobilization.

\section{Enzymatic polymerization results}

Monomer conversions (gravimetric), number average molecular weights $\left(\mathrm{M}_{\mathrm{n}}\right)$, and polydispersity indexes (PDI) of PCL samples at different temperatures were given in Table 1 depending on reaction time.

It can be clearly seen from Table 1 that, at $30^{\circ} \mathrm{C} \mathrm{M}_{\mathrm{n}}$ values increased with time and reached its highest value of $11100 \mathrm{~g} / \mathrm{mol}$ at the end of 72 hours reaction. At $40^{\circ} \mathrm{C}$, highest molecular weight was obtained as $11580 \mathrm{~g} / \mathrm{mol}$ after a shorter reaction period, 24 hours. Highest molecular weight was reached after 48 hours at $60^{\circ} \mathrm{C}$, which was $10840 \mathrm{~g} / \mathrm{mol}$. Finally, when the reaction temperature was increased to $80^{\circ} \mathrm{C}$, molecular weight of the polymer sample was reached to its highest value $(10900 \mathrm{~g} / \mathrm{mol})$ at the end of 48 hours.

For both temperature series it was common that, molecular weights and monomer conversions were decreased after certain reaction periods. This was mainly resulted from the shift of reaction to the inverse side by degradation activity of CALB. CALB used for ROP of $\varepsilon-C L$ is also responsible from degradation of $\mathrm{PCL}^{19}$.

To summarize, highest molecular weight $(11580 \mathrm{~g} / \mathrm{mol})$ was obtained at $40^{\circ} \mathrm{C}$ at the end of 24 hours. Further-
Table 1. Polymerization results obtained at different temperatures

\begin{tabular}{|l|r|c|r|r|}
\hline $\begin{array}{l}\text { Reaction } \\
\text { temperature } \\
{\left[{ }^{\circ} \mathrm{C}\right]}\end{array}$ & $\begin{array}{r}\text { Time } \\
{[\mathrm{h}]}\end{array}$ & $\begin{array}{c}\text { Conversion } \\
{[\%]^{\mathrm{a}}}\end{array}$ & $\begin{array}{c}\mathrm{M}_{\mathrm{n}} \\
{[\mathrm{g} / \mathrm{mol}]}\end{array}$ & PDI \\
\hline & 6 & 25.6 & 3350 & 1.3 \\
30 & 24 & 71.2 & 7115 & 1.4 \\
& 48 & 84.5 & 7480 & 1.4 \\
& 72 & 88.5 & 11100 & 1.5 \\
& 120 & 82.6 & 10180 & 1.5 \\
\hline & 6 & 29.6 & 5020 & 1.2 \\
40 & 24 & 83.8 & 11580 & 1.3 \\
& 48 & 83.1 & 7865 & 1.7 \\
& 72 & 82.5 & 7300 & 1.7 \\
& 120 & 81.5 & 7840 & 1.7 \\
\hline 60 & 6 & 45.7 & 6230 & 1.5 \\
& 24 & 80.7 & 8280 & 1.6 \\
& 48 & 85.6 & 10840 & 1.4 \\
& 72 & 71.5 & 8370 & 1.8 \\
80 & 120 & 70.3 & 7645 & 1.7 \\
\hline & 6 & 62.0 & 6300 & 1.5 \\
& 24 & 80.2 & 9910 & 1.5 \\
& 48 & 84.0 & 10900 & 1.5 \\
& 72 & 83.9 & 9190 & 1.5 \\
& 120 & 83.2 & 8770 & 1.7 \\
\hline
\end{tabular}

${ }^{a}$ Conversion was calculated gravimetrically.

more, molecular weights of polymer samples synthesized at $30^{\circ} \mathrm{C}$ were considerably high for a polymerization reaction. This makes the process low energy consuming besides being environmentally friendly. On the other hand, im-CALB was capable to catalyze polymerizations at $80^{\circ} \mathrm{C}$ as efficiently as at other temperatures. Such an enzymatic activity at a relatively high temperature shows the thermal stability of new biocatalyst.

Also, monomer conversions were proportional with molecular weights (Table 1). Highest monomer conversion was reached at $30^{\circ} \mathrm{C}$ at the end of 72 hours reaction period. However, after only 24 hours at both temperature series, monomer conversion reached to considerably high rates. Moreover, reaction speed at $80^{\circ} \mathrm{C}$ was the highest. At this temperature $62.0 \%$ monomer conversion was reached at the end of 6 hours. On the other hand, monomer conversions were tended to decrease after certain reaction times which was a result of reversible reaction ${ }^{19}$.

Moreover, PDI values were obtained around 1.5 or even less which was considerably narrow (Table 1$)^{\mathbf{2 0}}$.

\section{Characterization of polymer samples}

Characterizations were carried out for the polymer sample with highest molecular weight which was obtained at the end of 24 hours reaction at $40^{\circ} \mathrm{C}$.

FTIR spectrum of polymer sample was shown in Figure 3. The infrared bands of polymer sample synthesized by im-CALB were consistent with characteristic infrared bands of PCL, which were asymmetric $\mathrm{CH}_{2}$ bonds at 2945 $\mathrm{cm}^{-1}$, symmetric $\mathrm{CH}_{2}$ bonds at $2866 \mathrm{~cm}^{-1}$, carbonyl $(\mathrm{C}=\mathrm{O})$ bonds at $1720 \mathrm{~cm}^{-1}, \mathrm{C}-\mathrm{O}$ and C-C bonds seen in crystalline phase at $1293 \mathrm{~cm}^{-1}$, asymmetric C-O-C bonds at 1238 $\mathrm{cm}^{-1}$, and symmetric C-O-C bonds at $1167 \mathrm{~cm}^{-1}{ }^{21}$. This situation proved that the synthesized polymer was PCL.

Chemical structure of polymer sample was further characterized by ${ }^{1} \mathrm{H}$ NMR spectroscopy. The zoomed spectrum between $4.25 \mathrm{ppm}$ and $3.5 \mathrm{ppm}$ range was shown in Figure 4. The chemical shifts (ppm) at this range were as follow: $4.07 \mathrm{ppm}\left(\mathrm{t}, \mathrm{CH}_{2} \mathrm{O}\right)$ and 3.65 


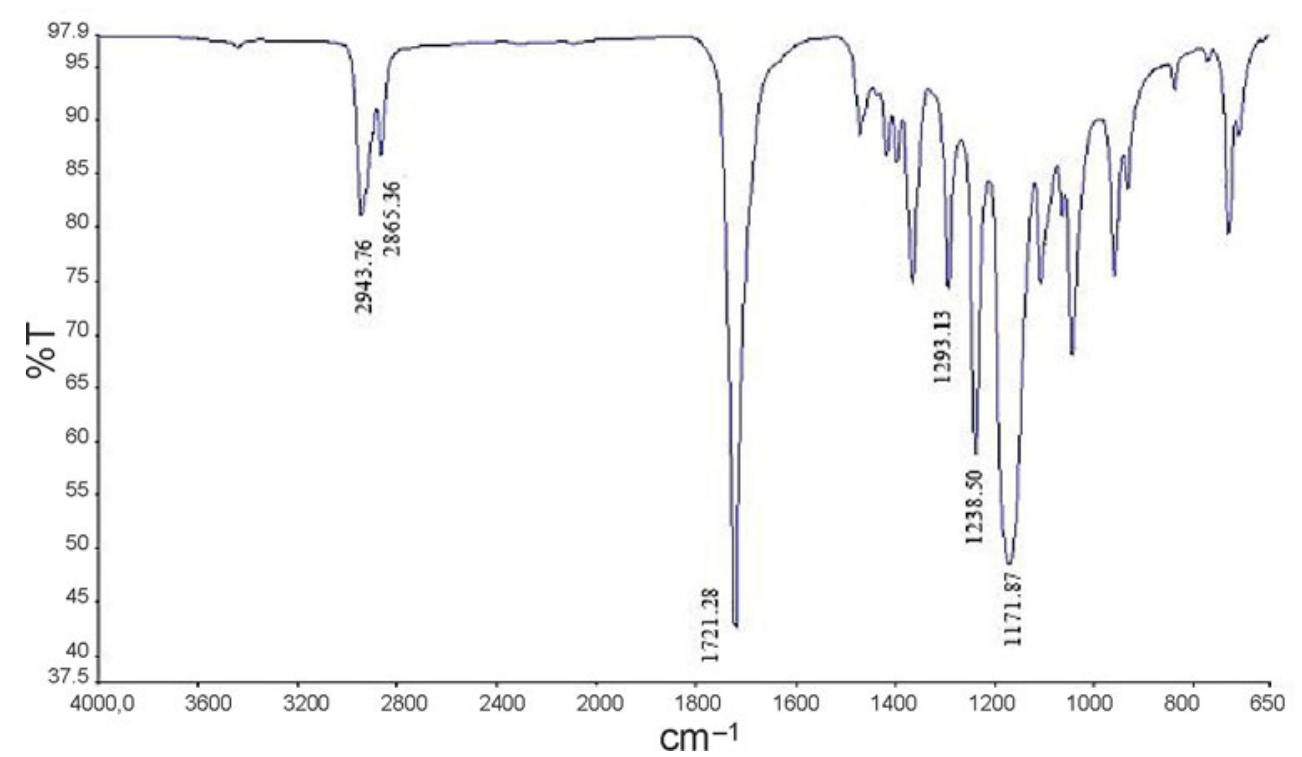

Figure 3. FTIR spectrum of polymer sample

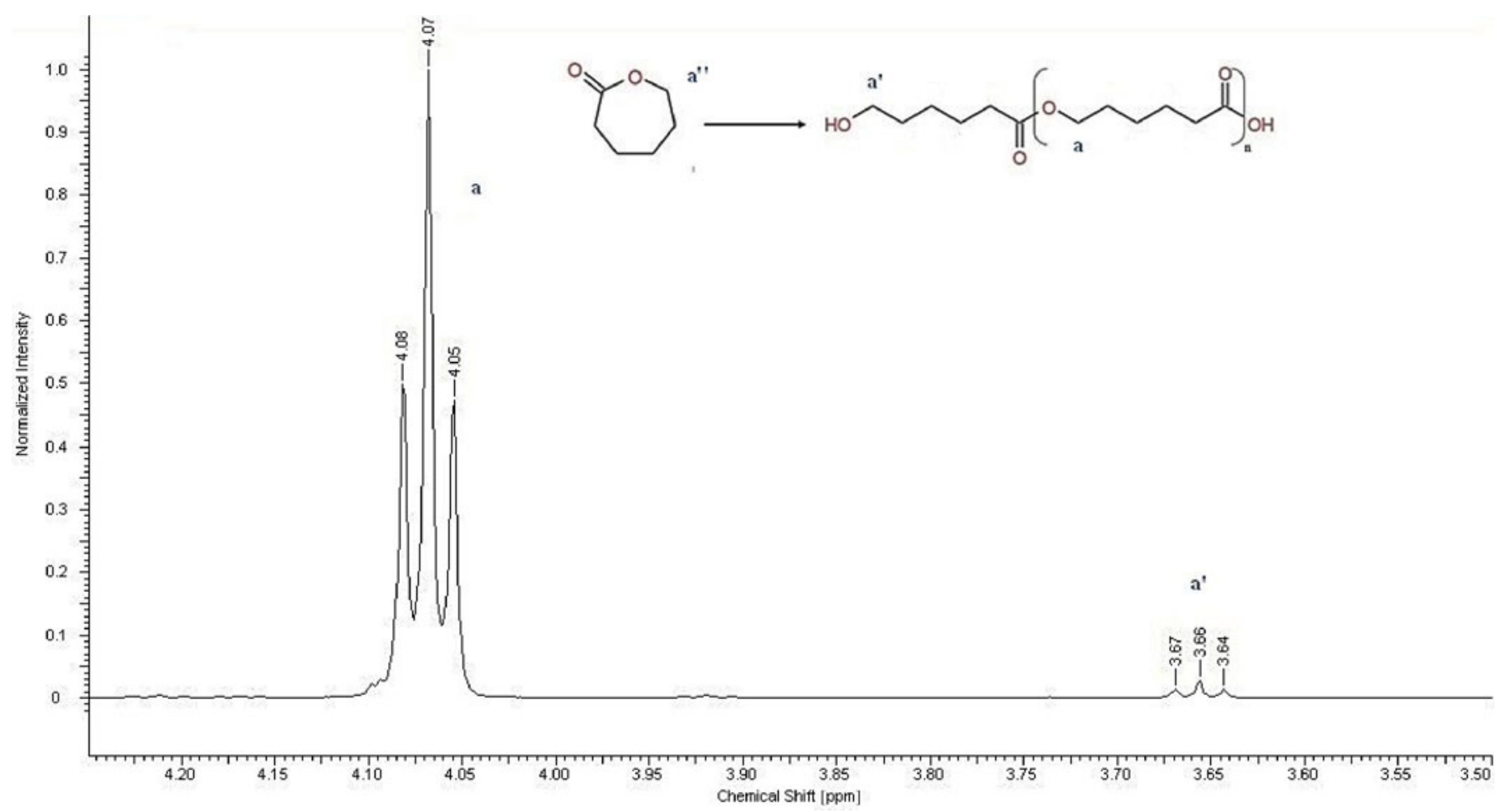

Figure 4. ${ }^{1} \mathrm{H}$ NMR spectrum of polymer sample

ppm ( $\mathrm{t}, \mathrm{CH}_{2} \mathrm{OH}$, end group) which were characteristic for $\mathrm{PCL}^{22}$.

Moreover, molecular weight of the PCL sample was also calculated from ${ }^{1} \mathrm{H}$ NMR spectrum. $\mathrm{M}_{\mathrm{n}, \mathrm{NMR}}$ value was obtained as $11495 \mathrm{~g} / \mathrm{mol}$ by using Equation 2 .

For the thermal characterization of polymer sample, TGA and DSC analyses were applied. TGA and DSC curves were given in Figure 5 and 6, respectively.

As clearly seen from TGA curves (Fig. 5), degradation temperature $\left(\mathrm{T}_{\mathrm{d}}\right)$ of PCL sample was determined as $403.5^{\circ} \mathrm{C}$. This result showed that, PCL synthesized with this new immobilized lipase had a high thermal stability.

Moreover, DSC was also applied for the determination of $\mathrm{T}_{\mathrm{m}}, \Delta \mathrm{H}_{\mathrm{m}}$, and $\mathrm{X}_{\mathrm{c}}$ values of PCL sample (Fig. 6). As seen from DSC thermogram (endodown graphic), $\mathrm{T}_{\mathrm{m}}$ value was obtained as $55^{\circ} \mathrm{C}$. This low $\mathrm{T}_{\mathrm{m}}$ value made the polymer sample easily reshaped. From the area of melting peak, $\Delta \mathrm{H}_{\mathrm{m}}$ was computed as $93.56 \mathrm{~J} / \mathrm{g}$. By using

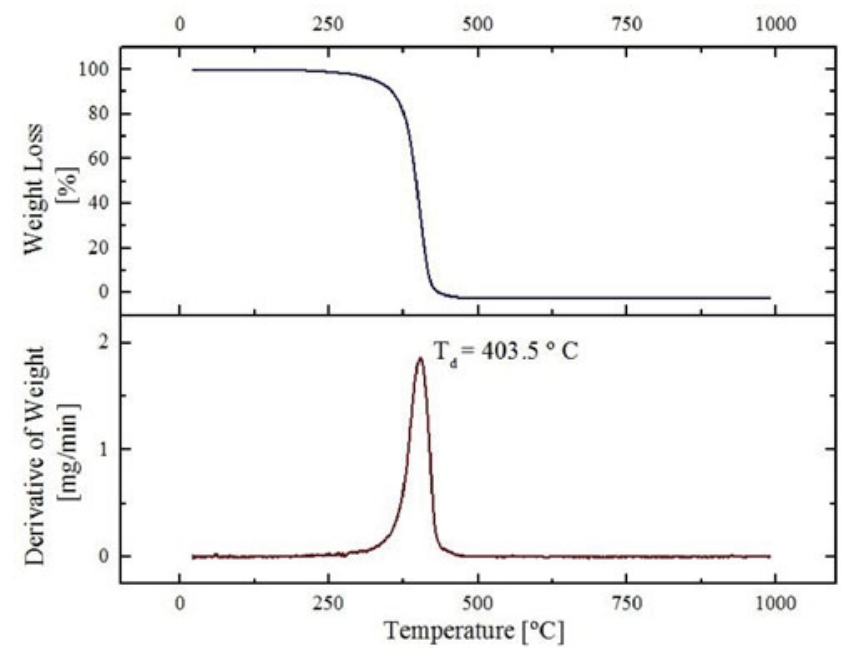

Figure 5. TGA curves of polymer sample 


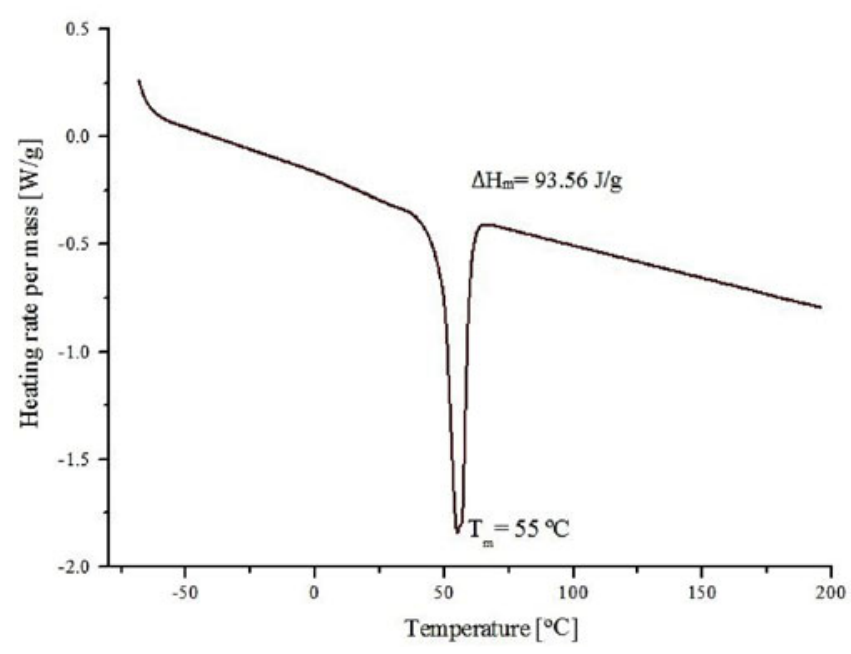

Table 2. Effect of enzyme concentration on polymerization

\begin{tabular}{|l|c|c|c|}
\hline $\begin{array}{l}\text { Enzyme concentration } \\
{[\%][\mathrm{w} / \mathrm{w}]}\end{array}$ & $\begin{array}{c}\text { Conversion } \\
{[\%]^{\mathrm{a}}}\end{array}$ & $\begin{array}{c}\mathrm{M}_{\mathrm{n}} \\
{[\mathrm{g} / \mathrm{mol}]}\end{array}$ & $\begin{array}{c}\mathrm{PDI} \\
{\left[\mathrm{M}_{\mathrm{w}} / \mathrm{M}_{\mathrm{n}}\right]}\end{array}$ \\
\hline 2.5 & 1.5 & - & - \\
5 & 21.8 & 6230 & 1.3 \\
10 & 48.8 & 7270 & 1.4 \\
20 & 83.8 & 11580 & 1.3 \\
\hline
\end{tabular}

${ }^{\mathrm{a} C}$ Conversion was calculated gravimetrically.

(w:w). Monomer conversion and molecular weight decreased with decreasing the enzyme concentration.

\section{Comparison with Commercial Lipases}

At best polymerization conditions, PCL synthesis was also carried out by using commercial lipases; Lipozyme ${ }^{\circledR}$ and Novozyme $435^{\circledR}$ (Fig. 8).

Figure 6. DSC thermogram of polymer sample

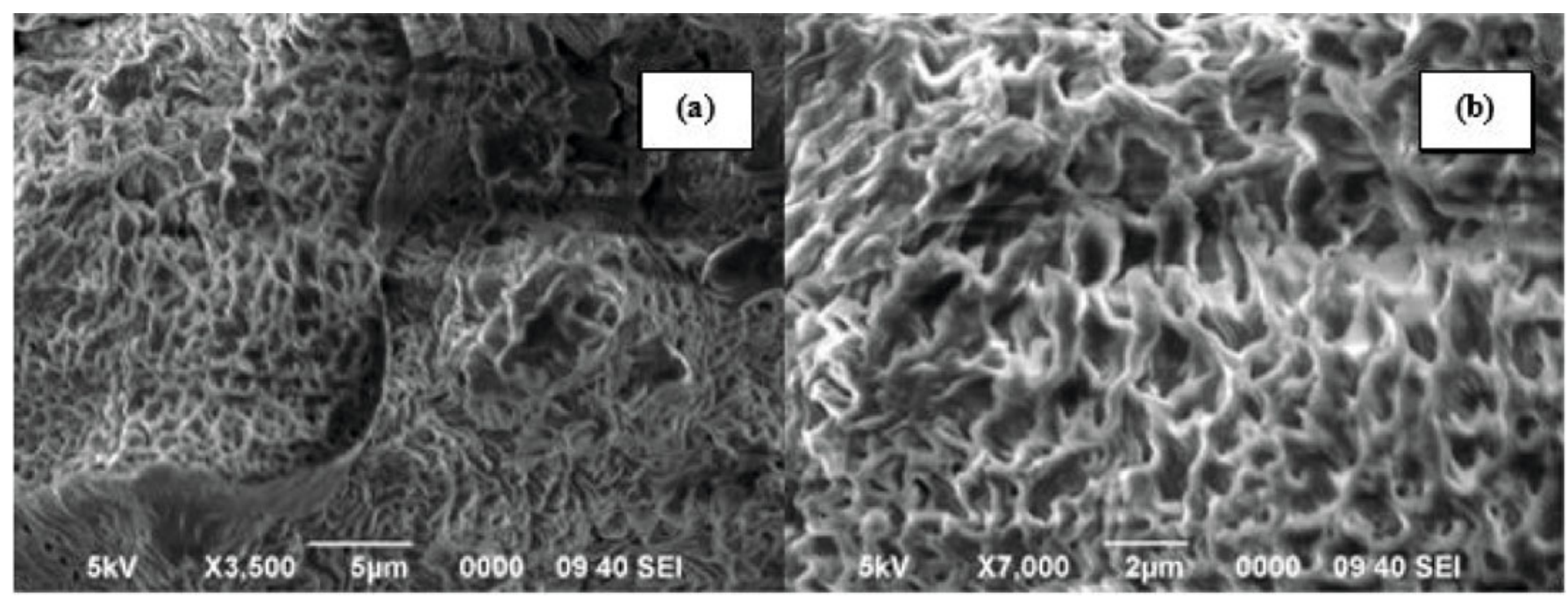

Figure 7. SEM images of polymer samples at 3500x (a) and 7000x (b) magnifications

Equation 1, crystallinity percentage $\left(\mathrm{X}_{\mathrm{c}}\right)$ was calculated as $67 \%$, which showed that polymer sample had a semi-crystalline structure.

Surface morphology of polymer sample was observed by SEM analysis. SEM images for different magnifications were shown in Figure 7.

As seen from Figure 7, the polymer sample had a foamlike structure. It can be safely suggested that the PCL sample can be used for tissue engineering successfully since its structure is suitable for cell attachment and growth $^{23,24}$.

\section{Effect of enzyme concentration on polymerization}

Effect of enzyme concentration on polymerization was investigated for the best synthesis conditions of the imCALB. In addition to $20 \%$ (w:w) enzyme concentration which was used in serial polymerization reactions, 2.5, 5 , and $10 \%$ (w:w) concentrations were also tried. Since a higher enzyme concentration was not economic, polymerizations with higher enzyme concentrations (>20\%) were not performed.

Polymerization results obtained with different enzyme concentrations at $40^{\circ} \mathrm{C}$ for 24 hours was given in Table 2 .

It can be clearly seen from Table 2 that, highest molecular weight and monomer conversion were obtained when im-CALB was used with a concentration of $20 \%$

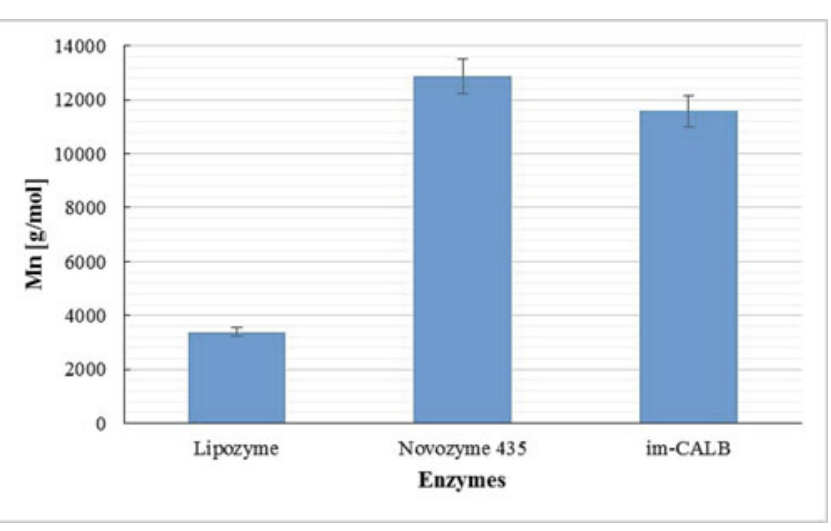

Figure 8. Molecular weights of polymer samples obtained via commercial lipases and im-CALB

As seen from Figure $8, M_{n}$ values obtained from the reaction carried out at $40^{\circ} \mathrm{C}$ for 24 hours with Lipozyme ${ }^{\circledR}$ and Novozyme $435^{\circledR}$ were $3380 \mathrm{~g} / \mathrm{mol}$ and $12860 \mathrm{~g} / \mathrm{mol}$, respectively. In addition, monomer conversions obtained by Lipozyme ${ }^{\circledR}$ and Novozyme $435^{\circledR}$ were $65.3 \%$ and $83.4 \%$, respectively. Lipozyme ${ }^{\circledR}$, which is the free form of CALB, resulted in lower molecular weight and monomer conversion when compared with Novozyme $435^{\circledR}$, which is the commercial immobilized form of CALB. This may a result of enhanced enzyme activity and stability by immobilization $^{7,25}$. Furthermore, at these conditions im-CALB 
catalyzed reaction resulted in an $11580 \mathrm{~g} / \mathrm{mol}$ molecularweighted PCL with $83.8 \%$ monomer conversion which was close to one that was obtained via Novozyme $435^{\circledR}$ catalysis. This result indicated that, the new immobilized lipase was as active as Novozyme $435^{\circledast}$ which is known with its high catalytic activity for the ROP of $\varepsilon-\mathrm{CL}^{26}$.

\section{CONCLUSIONS}

In this study, a by-product of rice production, rice husk, was utilized for lipase immobilization. We have extended our studies by showing a worthwhile application of our recently developed immobilized lipase. It was purposed to achieve ring opening polymerization of $\varepsilon$-CL via CALB immobilized on surface-modified rice husk ash by covalent binding (im-CALB). By using this enzyme highest molecular-weighted PCL was successfully obtained at $40^{\circ} \mathrm{C}$ after 24 hours reaction as $11580 \mathrm{~g} / \mathrm{mol}$. This molecular weight was very close to the PCL sample synthesized via Novozyme $435^{\circledR}$ at same reaction conditions. To date, Novozyme $435^{\circledR}$ was widely used for this process with high efficiency. Presently by this work, im-CALB can be safely suggested as an alternative biocatalyst for PCL synthesis. Low PDI values, high molecular weights and conversions showed the efficiency of the new enzyme. In addition, ability of catalysis over a wide range of temperature, $30-80^{\circ} \mathrm{C}$, showed the thermal stability of enzyme which was obtained by immobilization.

PCL sample was deeply characterized to prove the structure and other properties. The chemical composition was verified to be PCL by FTIR and ${ }^{1} \mathrm{H}$ NMR analyses. By TGA and DSC analyses, its superior thermal properties were characterized and the PCL sample was shown to be highly thermal stable and easily to be manufactured. Moreover, SEM pictures showed that, synthesized PCL had a suitable structure to be used for tissue engineering applications.

Consequently, this work makes possible a new route for PCL synthesis by suggesting a new lipase immobilized onto a renewable carrier in addition to providing a low energy consuming and green process.

\section{ACKNOWLEDGEMENTS}

Istanbul Technical University, Scientific Research Projects Coordination Department.

\section{LITERATURE CITED}

1. Ma, J., Li, Q., Song, B., Liu, D., Zheng, B., Zhang, Z. \& Feng, Y. (2009). Ring-opening polymerization of $\varepsilon$-caprolactone catalyzed by a novel thermophilic esterase from the archaeon Archaeoglobus fulgidus. J. Mol. Catal. B Enzym. 56, 151-157. DOI: 10.1016/j.molcatb.2008.03.012.

2. Li, Q., Li, G., Yu, S., Zhang, Z., Ma, F. \& Feng, Y. (2011). Ring-opening polymerization of $\varepsilon$-caprolactone catalyzed by a novel thermophilic lipase from Fervidobacterium nodosum. Process Biochem. 46, 253-257. DOI: 10.1016/j.procbio.2010.08.019.

3. Varma, I.K., Albertsson, A.C., Rajkhowa, R. \& Srivastava, R.K. (2005). Enzyme catalyzed synthesis of polyesters, Prog. Polym. Sci. 30, 949-981. DOI: 10.1016/j.progpolymsci.2005.06.010.

4. Albertsson, A.C. \& Srivastava, R.K. (2008). Recent developments in enzyme-catalyzed ring-opening polymerization. Adv. Drug Deliv. Rev. 60, 1077-1093. DOI: 10.1016/j. addr.2008.02.007.
5. Kobayashi, S. (2009). Recent developments in lipase-catalyzed synthesis of polyesters. Macromol. Rapid Commun. 30, 237-266. DOI: 10.1002/marc.200800690.

6. Kharrat, N., Ali, Y.B., Marzouk, S., Gargouri, Y.T. \& Karra-Châabouni, M. (2011). Immobilization of Rhizopus oryzae lipase on silica aerogels by adsorption: Comparison with the free enzyme. Process Biochem. 46, 1083-1089. DOI: 10.1016/j. procbio.2011.01.029.

7. Zheng, M.M., Lu, Y., Dong, L., Guo, P.M., Deng, Q.C., Li, W.L., Feng, Y.Q. \& Huang, F.H. (2012). Immobilization of Candida rugosa lipase on hydrophobic/strong cation-exchange functional silica particles for biocatalytic synthesis of phytosterol esters. Bioresour. Technol. 115, 141-146. DOI: 10.1016/j. biortech.2011.11.128.

8. Iyer, P.V. \& Ananthanarayan, L. (2008). Enzyme stability and stabilization-Aqueous and non-aqueous environment. Process Biochem. 43, 1019-1032. DOI: 10.1016/j.procbio.2008.06.004.

9. Lee, D.H., Park, C.H., Yeo, J.M. \& Kim, S.W. (2006). Lipase immobilization on silica gel using a cross-linking method.J. Ind. Eng. Chem. 12, 777-782.

10. Rodrigues, R.C., Berenguer-Murcia, A. \& Fernandez-Lafuente, R. (2011). Coupling chemical modification and immobilization to improve the catalytic performance of enzymes. Adv. Synth. Catal. 353, 2216-2238. DOI: 10.1002/adsc.201100163.

11. Della, V.P., Kühn, I. \& Hotza, D. (2002). Rice husk ash as an alternate source for active silica production. Mater. Lett. 57, 818-821. DOI: 10.1016/S0167-577X(02)00879-0.

12. Silva, A.L.P., Nascimento, R.G., Arakaki, L.N.H., Arakaki, T., Espínola, J.G.P. \& Fonseca, M.G. (2013). Organofunctionalized silica gel as a support for lipase. J. Non. Cryst. Solids 376, 139-144. DOI: 10.1016/j.jnoncrysol.2013.05.026.

13. Ulker, C. (2015). Immobilization of Lipase on an Inorganic Support Material and Polycaprolactone Synthesis. Istanbul Technical University, Istanbul, Turkey.

14. Harrison, K.L. \& Jenkins, M.J. (2004). The effect of crystallinity and water absorption on the dynamic mechanical relaxation behaviour of polycaprolactone. Polym. Int. 53, 1298-1304. DOI: 10.1002/pi.1517.

15. Öztürk-Düşkünkorur, H.M. (2012). Biopolymer Synthesis by Enzymatic Catalysis and Development of Nanohybrid Systems, Istanbul Technical University, Istanbul, Turkey.

16. Sha, K., Qin, L., Li, D., Liu, X. \& Wang, J. (2005). Synthesis and characterization of diblock and triblock copolymer by enzymatic ring-opening polymerization of $\varepsilon$-caprolactone and ATRP of styrene. Polym. Bull. 54, 1-9. DOI: 10.1007/ s00289-005-0341-1.

17. Valentini, L., Macan, J., Armentano, I., Mengoni, F. \& Kenny, J.M. (2006). Modification of fluorinated single-walled carbon nanotubes with aminosilane molecules. Carbon N.Y. 44, 2196-2201. DOI: 10.1016/j.carbon.2006.03.007.

18. Öney-Kıroğlu, C. (2014). Development and Characterization of Silica Based Super Insulation Materials. Istanbul Technical University, Istanbul, Turkey.

19. Ozsagiroglu, E., Iyisan, B. \& Avcibasi-Guvenilir, Y. (2013). Comparing the in-vitro biodegradation kinetics of commercial and synthesized polycaprolactone films in different enzyme solutions. Ekoloji 22, 90-96. DOI: 10.5053/ekoloji.2013.8611.

20. Singhal, A. (2011). The Pearson Guide to Objective Chemistry for the AIEEE. India: Dorling Kindersley.

21. Elzein, T., Nasser-Eddine, M., Delaite, C., Bistac, S. \& Dumas, P. (2004). FTIR study of polycaprolactone chain organization at interfaces. J. Coll. Interf. Sci. 273, 381-387. DOI: 10.1016/j.jcis.2004.02.001.

22. Kweon, H., Yoo, M.K., Park, I.K., Kim, T.H., Lee, H.C., Lee, H.S., Oh, J.S., Akaike. T. \& Cho, C.S. (2003). Novel degradable polycaprolactone networks for tissue engineering. Biomaterials 24, 801-808. DOI: 10.1016/S0142-9612(02)00370-8.

23. Woodruff, M.A. \& Hutmacher, D.W. (2010). The return of a forgotten polymer - Polycaprolactone in the 21st century. 
Prog. Polym. Sci. 35, 1217-1256. DOI: 10.1016/j.progpolymsci.2010.04.002.

24. Özsağıroğlu, E. (2011). Investigation of Effects of Reaction Mediums on Polycaprolactone Synthesis by Enzymatic Polymerization and Its Biodegradation. Istanbul Technical University, Istanbul, Turkey.

25. Rojo, S.R., Martín, A., Calvo, E.S. \& Cocero, M.J. (2009). Solubility of polycaprolactone in supercritical carbon dioxide with ethanol as cosolvent. J. Chem. Eng. Data 54, 962-965. DOI: $10.1021 /$ je8007364.

26. Öztürk-Düşkünkorur, H., Pollet, E., Phalip, V., Güvenilir, Y. \& Avérous, L. (2014). Lipase catalyzed synthesis of polycaprolactone and clay-based nanohybrids. Polymer 55, 1648-1655. DOI: 10.1016/j.polymer.2014.02.016. 